\title{
Sheep Use on Mountain Winter Range in
} New Mexico

\author{
KIRK C. McDANIEL AND JAMES A. TIEDEMAN
}

\begin{abstract}
Sheep were found to be affected by several factors related to the mountainous terrain. Slope steepness, percent bareground, and position on slope were the three most important factors influencing sheep distribution and utilization. Sheep favored mountain ridgetops for bedgrounds and grazing. Sheep utilization was relatively uniform on all side slopes less than $45 \%$, but utilization was reduced from $50 \%$ to $75 \%$ on steeper slopes. Sheep were not limited by distance from water in the mountainous country of this study area. Sheep used severely eroded slopes less than slightly eroded slopes.
\end{abstract}

Ranchers and range managers in mountainous country are faced with a difficult problem when determining proper use of range used readily by livestock. It is known in a general way that distribution is limited by steepness of slope, roughness of terrain, distance from water, and type and availability of forage (Mueggler 1965; Cook 1966). It is also generally known that sheep utilize steep mountain slopes more than cattle and can travel greater distances from water (Bowns 1971).

Cattle normally graze heavily on valley bottoms and more level land near water before moving onto rougher terrain. They tend to use some slopes extensively and others only slightly or not at all. In contrast, sheep normally graze heavily on the tops of ridges and tops of upper slopes before moving to valley bottoms.

During the period of the inter-agency range surveys (1934 to 1937), estimated capacity of mountain range was adjusted on the basis of percent slope in order to allow for the effect of topography (Interagency Range Survey Committee 1937, from Cook 1966). Other stocking rate adjustments were made based on distance from water, rockiness and prevalence of down timber. Today, carrying capacities are further adjusted based on minimal forage production standards and erodibility of the site (Instruction memorandum No. 78-509, BLM 1978).

Guidelines adopted by range managers which govern stocking rates in mountainous country are largely based on cattle research. Studies with cattle report the effect of availability of water (Holscher and Woolfolk 1953; Talbot 1926; Valentine 1947), the desirability of improving distribution of water (Costelle and Driscoll 1957; Goebel 1956), preference for certain plant communities (Miller and Krueger 1976), and how steep slopes and rough terrain hinder cattle movement (Mueggler 1965; Cook 1966). Similar studies with sheep, to our knowledge, have not been reported. Specific quantitative information about the effect of slope steepness and roughness of terrain on sheep distribution is needed to guide management effectively.

\section{Study Area and Procedure}

The study was conducted on the Bullis Spring Allotment within the Guadalupe District of the Lincoln National Forest. The allotment, managed by Carl and Don Lewis, is about $60 \mathrm{~km}$ southwest

\footnotetext{
This report is submitted as Journal Article 739, Agricultural Experiment Station, New Mexico State University, Las Cruces, New Mexico 88003

McDaniel is assistant professor, Department of Animal and Range Sciences, New Mexico State University, Las Cruces; Tiedeman was formerly assistant professor, Department of Animal and Range Sciences, New Mexico State University, but is presently range ecologist, Washington State University Farming Research Project, US-AID, Maseru, Lesotho. Funding for this project was provided by the Range Improvement Task Force, New Mexico State University.
}

of Hope, New Mexico. The area is coniferous woodland occurring on steep mountainous slopes with elevations ranging from 1,430 to $1,980 \mathrm{~m}$ and slope steepness from 0 to $70 \%$. The average precipitation is approximitely $30 \mathrm{~cm}$, with over $50 \%$ falling from July through October. Vegetation is a mixture of tree, shrub and herbaceous plants described by Donart et al. (1978) as typical of the Juniper-Pinyon-Oak Association. Pinyon-juniper (Pinus cembroides, Juniperus monosperma and $J$. deppeana) are dominant at higher elevations, with wavy leaf oak (Quercus undulata) occurring in scattered solid stands. Other common woody plants providing valuable browse for sheep and deer are mountain mahogany (Cercocarpus montanus), desert ceanothus (Ceanothus greggii), winterfat (Ceratoides lanata), and fourwing saltbush (Atriplex canescens). Blue grama (Bouteloua gracilis) is dominant on mesa tops and plateaus while sideoats grama (Boutelous curtipendula) and mountain muhly (Muhlenbergia montana) are more common on slopes of rugged hills. Plains lovegrass (Eragrostis intermedia) is an important cool-season grass occurring on the mountainous slopes.

Sites selected for vegetation and utilization sampling were identified according to steepness of slope, aspect, length of slope, distance to water, and dominant plant community. A U.S. Forest Service vegetation map showing range condition was used to stratify sampling areas further. Field measurements were taken in mid March 1979, within a fenced pasture of about 1,500 ha, where 702 sheep were grazed for the previous 3 months. New Mexico fine wool and Rambouillet were the principal breeds of sheep.

Distribution of sheep (relative use) was measured by pellet group counts on a series of belt transects located at 50 -m intervals up each slope. Transects were 3 meters wide and extended $150 \mathrm{~m}$ along the slope contour. The number of transects per slope varied, depending on length and uniformity of terrain. Additional transects were located on bottomlands along major and secondary drainages and on ridge tops.

Number of sheep pellet groups per transect were counted as an indicator of relative use as suggested by Mueggler (1965). Such an index has been used in cattle studies (Julander 1955; Cook 1966; Mueggler 1965), but to our knowledge similar research has not been conducted with sheep. Julander (1955) reported that cow chips were concentrated near water, salt, and bed grounds and were not necessarily distributed proportionately to where livestock fed. Cook (1966) stated that cow chip counts were unreliable indices of relative use of forage on the range, but might suggest relative time spent on various areas. The same is probably true for sheep.

Percent of plants grazed and percent of forage removed were also estimated along the $150-\mathrm{m}$ transect. The sampling unit was a quadrat $36 \times 72 \mathrm{~cm}$. Fifty quadrats per transect were taken. Percent ground cover of grasses, forbs, shrubs, litter, bare ground, gravel, and rock were estimated within each quadrat. Site factors recorded at each transect included percent slope measured with an Abney level, distance from water, distance upslope, aspect, range condition, and vegetation typc. Slope position was recorded at each site as either bottomland, lower $1 / 3$ of slope, midslope, upper $1 / 3$ of slope or ridgetop. Erosion condition classes were also determined at each site, by use of the Bureau of Land Mamage- 
ment soil surface factor (SSF) rating (Form 1221-2, BLM 1969).

The site factors affecting distribution and utilization on mountain slopes were analyzed statistically as independent variables. Relative use as indicated by pellet group counts, and the estimated percent of forage removed and percent of plants grazed were the dependent variables. Each transect represented a single observation. Certain site-related factors were grouped into select classes and analyzed further by analysis of variance with unequal numbers of observations. Mean separations were facilitated by selected single degree of freedom contrasts (Steel and Torrey 1960).

\section{Results and Discussion}

Sheep data were analyzed in a stepwise multiple regression problem similar to the scheme used on cattle data by Mueggler (1965) and Cook (1966). Percent of forage removed, percent of plants grazed and relative use were dependent variables. Fifteen site-related factors were the independent variables. The mean from each of the 77 transects represented an observation.

When the 15 independent variables were analyzed by the stepwise regression procedure with each of the 3 dependent variables, 8 of the 15 were found to have a significant effect $(P=0.05)$ upon one or more of the measurements of sheep use (Table 1). Slope position and percent baregound were the only independent variables significantly affecting all measurements of sheep use. Percent slope at the site affected 2 of the 3 dependent variables. Percent cover of grasses, gravel and shrubs; vegetation type; and the soil surface factor (SSF) estimate were significant with 1 of the 3 measures of sheep use.

Table 1. List of site-related factors which affect sheep distribution and utilization on mountain slopes.

\begin{tabular}{lccc}
\hline \hline & \multicolumn{3}{c}{ Partial regression coefficients } \\
\cline { 2 - 4 } & $\begin{array}{r}\text { \% forage } \\
\text { removed }\end{array}$ & $\begin{array}{c}\text { \% plants } \\
\text { grazed }\end{array}$ & $\begin{array}{c}\text { \% relative } \\
\text { use }\end{array}$ \\
\hline Site factors & 14.17 & -8.06 & -1.93 \\
Intercept & $6.26^{* *}$ & $4.16^{* *}$ & $0.79^{* *}$ \\
Slope position & $0.76^{* *}$ & $0.86^{* *}$ & $0.15^{* *}$ \\
\% bareground & $-1.25^{* *}$ & $-1.94^{* *}$ & \\
\% slope at site & $-0.36^{*}$ & & \\
Soil surface factor & $-0.43^{*}$ & & \\
\% shrub cover & & $0.24^{*}$ & \\
\% grass cover & & $-0.93^{*}$ & \\
Vegetation type & & & $-0.10^{* *}$ \\
\% gravel cover & & 0.63 & 0.38 \\
$R^{2}$ & 0.60 & 0.63 & \\
Standard error & 1.04 & 0.72 & 0.20 \\
& & &
\end{tabular}

${ }^{*} P<0.05$

$* * P<0.01$

When the 15 independent variables were analyzed with percent of forage removed as the dependent variable, a multiple correlation coefficient of 0.77 was obtained $(F=12.88 ; 6$ and $58 \mathrm{df})$. Position on slope, percent bareground, and percent slope at the site were highly significant ( $F=33.8,11.4$ and 12.8 , respectively) and accounted for $71 \%$ of the variation in percent of forage removed. Individually they were less effective. The simple correlation coefficient for position on slope and percent of forage removed is 0.35 , and that for percent bareground and percent of forage removed is 0.44 . The correlation coefficient for percent slope at site and percent of forage removed is -0.25 . Thus position on slope, percent bareground and percent slope at site account for only 12,20 , and 6 percent, respectively, in the variation in percent of forage removed. The inability of a single site-related factor to account satisfactorily for the variation in sheep use on mountain slopes is similar to results reported on cattle by Cook (1966). These data suggest several site-related factors must be considered in order to predict grazing use by sheep on mountain pastures reliably.

An analysis of the 15 independent variables and percent of plants grazed yielded results similar to those from the regression with percent of forage removed. Again, slope position, percent bareground and percent slope at the site were highly significant. These three variables together accounted for $75 \%$ of the variation in percent of plants grazed. Percent grass cover and vegetation type were significant at the 0.05 probability level. When all the independent variables were analyzed with percent of plants grazed, a multiple correlation coefficient of 0.79 was obtained $(F=18.14 ; 5$ and $58 \mathrm{df}$ ).

The stepwise regression procedure for the site-related factors and the dependent variable relative use yielded the lowest multiple coefficient of determination of the three models tested $\left(R^{2}=0.38\right.$ compared to 0.59 and 0.63 for percent of forage removed and percent of plants grazed, respectively). Slope position, percent bareground, and percent gravel were all highly significant $(F=$ $15.85,13.29$ and 7.99 , respectively). Sheep pellet groups, which were used as the index for relative use, were concentrated at bedding grounds and along trails to water and trails along the slope contour. They were not well distributed throughout grazed areas, and thus are probably not as good an indicator of sheep use as percent of forage removed or percent of plants grazed.

As would be expected, increasing slope negatively affected sheep use (Table 1). However, an examination of the means within various slope classes reveals little variation in sheep use on all slopes less than $45 \%$ (Table 2). Utilization on slopes greater than $45 \%$ was approximately $55 \%$ to $75 \%$ less than that measured on the more gradual slopes. Sheep used all slopes regardless of steepness, but when terrain was especially rough the animals mostly trailed through the area making little use of the available forage.

The steepest slopes occurred mainly on the mid and upper one-third slope positions. Significantly less forage was removed and fewer plants were grazed on the three midslope positions and the bottomland as compared to the ridgetops (Table 2). All bedding grounds observed in the pasture were located on mountain ridges and saddles and accounted largely for the greater use. Sheep use on bedding grounds was particularly heavy with up to $70 \%$ of the forage removed from all areas generally less than I hectare in size. Unherded sheep tend to use the same areas for bedding from night-to-night and from year-to-year. Over time this continual use results in a sparse vegetative cover and an increased amount of exposed bareground and gravel.

Table 2. Sheep use as determined by percent of forage removed, percent of plants grazed, and relative use on different slope classes, slope positions and soil surface factors.

\begin{tabular}{|c|c|c|c|c|}
\hline Site factors & $\mathbf{N}$ & $\begin{array}{l}\text { Percent of } \\
\text { forage } \\
\text { removed }\end{array}$ & $\begin{array}{c}\text { Percent of } \\
\text { plants grazed }\end{array}$ & $\begin{array}{c}\text { Percent } \\
\text { relative } \\
\text { use }\end{array}$ \\
\hline \multicolumn{5}{|l|}{ Slope class (\%) } \\
\hline $0-7$ & 12 & $18.4 \mathrm{a}^{1}$ & $16.8 \mathrm{a}$ & $19.0 \mathrm{a}$ \\
\hline $8-14$ & 10 & $20.7 \mathrm{a}$ & $19.0 \mathrm{a}$ & $20.0 \mathrm{a}$ \\
\hline $15-24$ & 9 & $21.8 \mathrm{a}$ & $16.6 \mathrm{a}$ & $19.2 \mathrm{a}$ \\
\hline $25-34$ & 10 & $18.3 \mathrm{a}$ & $12.0 \mathrm{a}$ & $13.4 \mathrm{a}$ \\
\hline $35-44$ & 13 & $18.6 \mathrm{a}$ & $13.9 \mathrm{a}$ & $20.1 \mathrm{a}$ \\
\hline $45-54$ & 9 & $8.8 \mathrm{~b}$ & $5.6 \mathrm{~b}$ & $3.9 \mathrm{~b}$ \\
\hline $55-64$ & 14 & $5.7 \mathrm{~b}$ & $5.4 \mathrm{~b}$ & $5.7 \mathrm{~b}$ \\
\hline \multicolumn{5}{|l|}{ Slope position } \\
\hline Bottomland & 15 & $14.9 \mathrm{a}$ & $14.7 \mathrm{a}$ & $19.0 \mathrm{a}$ \\
\hline Low $1 / 3$ slope & 16 & $13.3 \mathrm{a}$ & $11.3 \mathrm{a}$ & $8.0 \mathrm{a}$ \\
\hline Mid 1/3 slope & 19 & $12.0 \mathrm{a}$ & $7.6 \mathrm{a}$ & $6.4 \mathrm{a}$ \\
\hline Upper $1 / 3$ slope & 17 & $12.5 \mathrm{a}$ & $9.9 \mathrm{a}$ & $12.2 \mathrm{a}$ \\
\hline Ridgetop & 10 & $39.5 \mathrm{~b}$ & $25.6 \mathrm{~b}$ & $54.4 \mathrm{~b}$ \\
\hline
\end{tabular}

Soil surface factor

$\begin{array}{lrrrr}\text { Stable }(0-20) & 5 & 22.8 \mathrm{a} & 12.1 \mathrm{a} & 27.7 \mathrm{a} \\ \text { Slight }(21-40) & 34 & 20.6 \mathrm{a} & 13.2 \mathrm{a} & 22.3 \mathrm{a} \\ \text { Moderate }(41-60) & 31 & 13.9 \mathrm{~b} & 13.3 \mathrm{a} & 18.7 \mathrm{a} \\ \text { Severe }(61-80) & 7 & 7.1 \mathrm{c} & 7.3 \mathrm{~b} & 8.9 \mathrm{~b}\end{array}$

'Means followed by the same letter are not significantly different at the $5 \%$ level of probability. 
Determination of erosion condition classes using the Bureau of Land Management soil surface factor (SSF) was estimated to obtain a measure of relative difference among areas rather than an absolute determination of erosion taking place in the pasture. Sheep use, when separated into four erosion classes, was reduced as the SSF became more severe (Table 2). More forage was removed from areas rated as stable or slightly eroded than from areas in the moderate erosion class. The amount of forage removed from areas of the moderate class was intermediate to that removed from areas of the severely eroded class. Only $7 \%$ of the forage was utilized from areas rated as severely eroded compared to about $20 \%$ from areas rated as stable or slightly eroded.

Sheep use on different aspects varied but did not significantly contribute to the variation explained by the multiple regression analysis (Table 1). A greater percent of forage was removed and more plants were grazed on south and east-exposed slopes than on north and west-facing slopes (Table 3 ). The pasture had a nearly equal amount of slopes facing predominantly east or west; however, the west slopes were steeper. The west slopes ranged from $8 \%$ to $60 \%$ in steepness and averaged $35 \%$, whereas the east slopes range from $3 \%$ to $42 \%$ and averaged only $16 \%$. North slopes averaged $40 \%$ whereas south slopes averaged $28 \%$ and did not exceed $42 \%$ in steepness. This information is particularly useful for management purposes. The data provide important evidence on where sheep spent the greatest portion of their time grazing. In this study, the sheep utilized a greater percent of forage from the less steep east slopes than from the steeper west slopes. For this example, it would be most important to monitor utilization on the east slopes to determine proper use.

Table 3. Sheep use as determined by percent of forage removed, percent of plants grazed and relative use at different distances from water and slope aspects.

\begin{tabular}{lcccc}
\hline Site factors & $\mathrm{N}$ & $\begin{array}{c}\text { Percent of } \\
\text { forage } \\
\text { removed }\end{array}$ & $\begin{array}{c}\text { Percent of } \\
\text { plants } \\
\text { grazed }\end{array}$ & $\begin{array}{c}\text { Percent } \\
\text { relative use }\end{array}$ \\
\hline $\begin{array}{c}\text { Distance from water } \\
\quad 0-500 \mathrm{~m}\end{array}$ & 16 & $16.9 \mathrm{a}^{1}$ & $16.3 \mathrm{a}$ & $18.1 \mathrm{a}$ \\
$500-1000 \mathrm{~m}$ & 22 & $17.3 \mathrm{a}$ & $13.0 \mathrm{a}$ & $17.0 \mathrm{a}$ \\
$1000-1500 \mathrm{~m}$ & 25 & $16.7 \mathrm{a}$ & $20.1 \mathrm{a}$ & $16.0 \mathrm{a}$ \\
$1500-2000 \mathrm{~m}$ & 3 & $20.4 \mathrm{a}$ & $20.1 \mathrm{a}$ & $16.0 \mathrm{a}$ \\
$2000-2400 \mathrm{~m}$ & 11 & $12.2 \mathrm{a}$ & $6.9 \mathrm{a}$ & $12.3 \mathrm{a}$ \\
& & & & \\
Aspect & 18 & $12.6 \mathrm{a}$ & $7.1 \mathrm{a}$ & $10.7 \mathrm{a}$ \\
North & 17 & $19.9 \mathrm{~b}$ & $16.1 \mathrm{~b}$ & $26.8 \mathrm{~b}$ \\
South & 19 & $22.4 \mathrm{~b}$ & $17.3 \mathrm{~b}$ & $43.7 \mathrm{c}$ \\
East & 23 & $12.2 \mathrm{a}$ & $10.4 \mathrm{a}$ & $18.9 \mathrm{ab}$ \\
West & & &
\end{tabular}

IMeans followed by the same letter are not significantly different at the $5 \%$ level of probability.

Distance from water was not limiting as a near equal amount of forage was removed from $2,000-2,400 \mathrm{~m}$ from water $(12.2 \%)$ as from $0-500 \mathrm{~m}$ from water $(16.9 \%)$ (Table 3$)$. Water was well distributed in the pasture and stock tanks were available on the bottoms and near the top of the mountain slope. Periodic snows also occurred during the winter grazing, providing additional moisture. The requirement for free water appears to be less for sheep than for cattle and in this study was not considered to be a limiting factor.

\section{Summary and Conclusions}

Sheep use on mountain slopes was found to be affected by several factors related to the mountainous terrain. Slope steepness, percent bareground, and position on slope were most important in influencing distribution and utilization of sheep on the mountain pasture. Sheep distribution was given as relative use on various portions of the pasture by counting fecal groups. The approach was similar to that used for cattle by Mueggler (1965). Utilization was determined from estimates of percent of forage removed and percent of plant grazed.

The amount of forage removed by sheep ranged from $3 \%$ to $65 \%$ and averaged $16.8 \%$. Use on mountain mahogany, the only woody plant observed as browsed, ranged from 0 to $65 \%$ and averaged $11.0 \%$. The greatest utilization was near bedgrounds located on the mountain ridgetops and saddles. The least utilization occured on slopes greater than $45 \%$ occupying mid slope positions.

Of the 15 independent variables studied, 8 were found significantly correlated to utilization or distribution when analyzed as a multiple regression model. These are, in order of importance:
1. Slope position
2. \% bareground
3. \% slope at site
4. \% gravel
5. Soil surface factor
6. \% grass cover
7. \% shrub cover
8. Vegetation type

Those factors measured that were not significantly correlated to sheep use on mountain slopes in this study were:

1. Distance from water

2. Aspect

3. $\%$ forb cover

4. $\%$ litter cover

5. \% rock cover

6. Range condition

7. Total vegetation cover

No one factor could be used as a reliable index to predict sheep use. Cook (1966) reported similar results with cattle. However, the combination of factors which affect sheep use are not the same as for cattle. Mueggler (1965) reported that cattle favored bottomlands in mountainous country and that relative use diminished exponentially as the animals moved upslope. In this study sheep favored the tops of mountain slopes and utilization was relatively uniform on all slopes less than $45 \%$. Additionally, sheep do not appear to be limited by distance from water to the same degree as cattle.

\section{Literature Cited}

Bowns, J.E. 1971. Sheep behavior under unherded condition on mountain summer ranges. J. Range Manage. 24:104-109.

Cook, C.W. 1966. Factors affecting utilization of mountain slopes by cattle. J. Range Manage. 19:200-204.

Costello, D.F., and R.S. Driscoll. 1957. Hauling water for range cattle. U.S. Dep. Agr. Leaflet 419.6 p.

Donart, G.B., D.D. Sylvester, and W.C. Hickey. 1978. Potential natural vegetation in New Mexico. Map prepared by USDA-SCS, Portland, Ore.

Goebel, Carl J. 1956. Water development on the Starkey Experimental Forest and Range. J. Range Manage. 9:232-234.

Holscher, C.E., and E.J. Woolfork. 1953. Forage utilization by cattle on northern Great Plains ranges. U.S. Dep. Agr. Circ. 918. 27 p.

Instruction memorandum No. 78-509. 1978. Rangeland suitability for livestock grazing-concepts, criteria and standards. Dated Sept. 14, 1978. Bureau of Land Management. U.S. Dep. of Interior, Washington, D.C.

Interagency Range Survey Committee. 1937. Instructions for range surveys. Interagency Range Survey Conference, April 24, 1937. Salt Lake City, Utah.

Julander, 0. 1955. Determining grazing use by cow-chip counts. J. Range Manage. 8:182.

Miller, R.F., and W.C. Krueger. 1976. Cattle use on summer foothill rangelands in northeastern Oregon. J. Range Manage. 29:367-371.

Mueggler, W.E. 1965. Cattle distribution on steep slopes. J. Range Manage. 18:255-257.

Steel, R.G.D., and J.H. Torrie. 1960. Principles and procedures of statistics. McGraw-Hill, New York. 481 p.

Talbot, M.W. 1926. Range watering places in the Southwest. U.S. Dep. Agr. Bull. 1358. 44 p.

Valentine, K.A. 1947. Distance from water as a fact or in grazing capacity of rangeland. J. Forestry 45:749-754.

Form 1221-2, BLM 1969. Watershed Conservation and Development System-7322. Bureau of Land Management. U.S. Dep. of the Interior, Washington, D.C. 